NOTE

\title{
Typing of French isolates of infectious haematopoietic necrosis virus (IHNV) with monoclonal antibodies using indirect immunofluorescence
}

\author{
M. Danton ${ }^{1}$, S. S. Ristow ${ }^{2}$, A. M. Hattenberger-Baudouy ${ }^{1}$, P. de Kinkelin ${ }^{3}{ }^{*}$ \\ ${ }^{1}$ Centre National d'Etudes Vétérinaires et Alimentaires, LCRV, Unité d'Ichtyopathologie Continentale, BP 67, F-94703 Maisons-Alfort, France \\ ${ }^{2}$ Department of Animal Sciences, Washington State University, Pullman, Washington 99164, USA \\ ${ }^{3}$ Institut National de la Recherche Agronomique, Unité de Virologie et d'Immunologie Moléculaires, F-78352 Jouy-en-Josas, France
}

\begin{abstract}
Following the first isolation of infectious haematopoietic necrosis virus (IHNV) in France, many other isolates of the virus have been recovered from rainbow trout populations. Of the 27 isolates typed using an indirect immunofluorescence (IIF) test with mouse monoclonal antibodies (MAb), only 5 of the French isolates were recognized by MAb 1NDW14D, previously considered to be a universal IF reagent for IHNV. In contrast, all 27 isolates shared the nucleocapsid epitope identified by MAb 2NH105B, currently thought to be specific for IHNV of electropherotype 2, although the French isolates did not appear to belong to this electropherotype. Considerable variation was noted among the isolates in other nucleocapsid epitopes, suggesting that some of the isolates have been present among rainbow trout, in Europe or elsewhere, for sufficient time to evolve separately. Practically speaking, a multivalent IHNV reagent for IIF based upon MAbs should encompass both MAbs 1NDW14D and 2NH105B, especially if intended for European use.
\end{abstract}

KEY WORDS: Rhabdovirus - Infectious haematopoietic necrosis virus - Antigenicity - Monoclonal antibodies - Immunofluorescence $\cdot$ Rainbow trout

Infectious haematopoietic necrosis virus (IHNV) is an economically important rhabdovirus in trout and salmon farming and fisheries. Epizootics of IHNV are particularly devastating in rainbow trout hatcheries, sometimes inflicting complete mortality in a population; the survivors may show scoliosis, and many of them become asymptomatic virus carriers. IHNV was first thought to infect primarily the juvenile stages of trout, but more recently it has been shown to infect larger fish (Busch 1983.)

Although first characterized in the United States (Wolf 1988), IHNV has been found in other countries. It

-Addressee for correspondence appeared in Hokkaido Island, Japan, in 1968 following a shipment of contaminated salmon eggs from Alaska, USA (Sano et al. 1977). Recently, the presence of IHNV has been documented in Taiwan (Chen et al. 1985) and in China (Luqi \& Zhizhuang 1988). Isolation of IHNV in Europe was first reported in France (Anonymous 1987), then in Italy (Bovo et al. 1987). All of these virus isolates belong to a single serotype identified by McCain et al. (1971), for isolates found in the Pacific Northwest and California, USA.

Characterization of the first European isolates (Arkush et al. 1989) and a comparison with U.S. isolates was made by electropherotyping (Leong et al. 1981) as described by Hsu et al. (1986) and by a neutralization test using monoclonal antibodies prepared by Winton et al. (1988). The 3 European isolates tested did not fit in the electropherotypic grouping established with North American IHNV isolates, although they were grossly neutralized similar to the Lewis River and Cedar River isolates, both originating in Washington State, USA. The French isolates exhibited a slightly different neutralization index with a single monoclonal antibody when compared to a contemporary isolate from Italy (Bovo et al. 1987), indicating a possible antigenic difference between the 2 European forms of the virus.

Following the isolation of IHNV in France, an extensive epidemiological survey was conducted on French fish farms (unpubl.) which resulted in the recovery of 26 other IHNV isolates. The purpose of the present study was to type the collection of 27 French isolates using a limited panel of monoclonal antibodies made against North American isolates (Ristow \& Arnzen de Avila 1991), and to look for antigenic relationships among the French isolates and between the North 
American and French isolates. Finally, we wished to determine whether a particular monoclonal antibody, 1NDW14D, considered to identify a conserved epitope in the nucleoprotein of all North American isolates (Ristow \& Arnzen de Avila 1991), would also universally react with all French isolates.

Materials and methods. Fish cells: The carp skin cell line Epithelioma papulosum cyprini, EPC (Fijan et al. 1983) was grown at $30^{\circ} \mathrm{C}$ in Stoker's medium. This medium was buffered at $\mathrm{pH} 7.4$ with Tris- $\mathrm{HCl}(0.16 \mathrm{M})$ and supplemented with 10\% tryptose phosphate (DIFCO), 10\% fetal calf serum (GIBCO BRL) and antibiotics (Bipenicillin $100 \mathrm{IU} \mathrm{ml} \mathrm{m}^{-1}$ and Dihydrostreptomycin $100 \mu \mathrm{g} \mathrm{ml}^{-1}$ ). For virus isolation and production, the cells were incubated at $15^{\circ} \mathrm{C}$, and $\mathrm{pH}$ and serum content of the maintainance medium were adjusted to 7.6 and $2 \%$ respectively.

Viruses: The reference IHNV isolates Round Butte 76 (RB), Western Regional Aquaculture Center (WRAC), Sacramento River Chinook Virus (SRCV) belonging to electropherotypes 1,2 and 3 respectively (Hsu et al. 1986) were supplied by Dr James Winton, National Fisheries Research Center, Seattle, WA, USA. The isolate IHNV/71 (courtesy of Dr Donald Amend), electropherically untyped, was used by our laboratory in France as the reference strain of IHNV until 1988 and was used to prepare rabbit serum to IHNV (no. INRA 709).

The 27 French virus isolates employed in this study originated either from clinically infected rainbow trout Oncorhynchus mykiss alevins and fingerlings (22 isolates) or from asymptomatic virus carriers (4 isolates derived from ovarian fluid and milt and 1 from a pool of kidney, spleen and brain). Viruses were isolated and identified according to standard procedures (de Kinkelin et al. 1985). Briefly, EPC cells monolayers in 4-well plastic cell culture plates (Nunc, Denmark) were inoculated with $0.1 \mathrm{ml}$ of 10 -fold step dilutions of organ homogenates or sexual products. After the cytopathic effect was complete, virus identification was made by sero-neutralization test (SNT) (end point technique) performed with infected cell culture supernatants using rabbit serum to IHNV. The absence of viral haemorrhagic septicemia virus (VHSV) was checked in parallel infected samples by another SNT using homologous antibodies. Small batches of each of the IHNV isolates were prepared in EPC cells, titered to establish a working dilution, aliquoted and frozen at $-80^{\circ} \mathrm{C}$.

Monoclonal antibodies: Monoclonal antibodies to the glycoproteins and nucleoproteins of a number of different isolates of IHN virus were produced as described previously (Ristow \& Arnzen 1989, Ristow \& Arnzen de Avila 1991). In this study, 6 of these monoclonal antibodies were utilized in indirect fluorescence to screen the French isolates: 1NDW14D (produced by an immunization with the nucleoprotein of a Dworshak isolate 2 and found to react with all 28 North American isolates tested); 1NDW19I (also produced from an immunization to Dworshak isolate nucleoprotein, but not reacting with all North American isolates); 1NC027G (an anti-nucleoprotein antibody produced from a fusion against a Coleman isolate from chinook salmon Oncorhynchus tshawytscha); 3GH127B and 1NH139P (anti-glycoprotein and anti-nucleoprotein antibodies produced in a fusion in which the glycoprotein and the nucleoprotein of Hagerman virus, isolate 039-82SR, were the respective immunogens); and 2NH105B (an anti-nucleoprotein antibody made by immunization with the nucleoprotein of Hagerman virus 039-82SR), which recognizes electrophoretic type 2 IHNV (Hsu et al. 1986, Ristow \& Arnzen 1989).

Indirect immunofluorescence test: EPC cells grown in 96-well microplates for $16 \mathrm{~h}$ were infected with $100 \mu \mathrm{l}$ of each virus to be tested at a dilution 1:100 (500 pfu per well, 1 plate per virus). After 30 to $36 \mathrm{~h}$ of incubation at $15^{\circ} \mathrm{C}$, the infected cell cultures were fixed for $30 \mathrm{~min}$ at $-20^{\circ} \mathrm{C}$ in $90 \%$ acetone in water, dried and stored at $-20^{\circ} \mathrm{C}$ in sealed plastic bags until used.

Prior to performing the study with the French virus isolates, the working dilution for each MAb was established using the reference American isolates and was found to be 1:25 for the cell culture supernatants from hybridomas 3GH127B and 1NH139P, 1:50 for those from hybridomas 1NDW14D, 1NW19I and 1NC027G, and 1:5000 for the ascites fluid from hybridoma 2NH105B.

For immunological analysis of the French isolates, the virus infected cell monolayers were rehydrated with PBS $(0.01 \mathrm{M}$ at $\mathrm{pH}$ 7.3) and individual wells inoculated with 1 of the 6 MAbs or with polyclonal serum INRA 709. The plates were incubated for $90 \mathrm{~min}$ at $37^{\circ} \mathrm{C}$. After 3 rinses with PBS, binding of the antibody was revealed using a fluorescein-conjugated second antibody incubated for $1 \mathrm{~h}$ at $37^{\circ} \mathrm{C}$ according to the recommendations of the manufacturer (Biosys, Compiègne, France). The cell monolayers were stained with Evans blue $0.05 \%$, rinsed 5 times with PBS, and observed with an inverted fluorescence microscope (Zeiss type IM35) at magnifications of $63 x$ and $160 x$.

Results and discussion. The results of our immunological analysis are given in Table 1 grouped by decreasing order of reactivity with the MAbs. All the IHN virus isolates were recognized by polyclonal rabbit serum INRA 709. As expected, the 4 American reference isolates were also recognized by MAb 1 NDW14D; however, only 5 of the 27 French isolates reacted with this MAb. It thus appears that MAb 1NDW14D can no 
Table 1. Analysis of French IHNV isolates by indirect immunofluorescence with 6 monoclonal antibodies to American virus strains. WRAC: Western Regional Aquaculture Center; IHNV/71. isolate supplied by D. Amend in 1971; RB: Round Butte 76; SRCV: Sacramento River Chinook Virus; I, II, III: electropherotypes defined by Hsu et al. (1986). +: positive reaction; -: negative reaction; wk: weak reaction

\begin{tabular}{|c|c|c|c|c|c|c|c|}
\hline \multirow[t]{2}{*}{ Isolates } & \multirow{2}{*}{$\begin{array}{l}\text { Rabbit serum } \\
\text { no. } 709\end{array}$} & \multicolumn{6}{|c|}{ Monoclonal antibodies } \\
\hline & & $2 \mathrm{NH} 105 \mathrm{~B}$ & $1 \mathrm{NCO} 27 \mathrm{G}$ & $1 \mathrm{NH} 139 \mathrm{P}$ & 1NDW19I & 1NDW14D & $3 \mathrm{GH} 127 \mathrm{~B}$ \\
\hline WRAC(II) & + & + & + & + & + & + & - \\
\hline $51 / 90$ & + & + & + & + & + & + & - \\
\hline $172 / 91$ & + & + & + & + & + & + & - \\
\hline IHNV/71 & + & + & + & + & + & + & - \\
\hline $69 / 87$ & + & + & + & + & + & - & - \\
\hline $147 / 90$ & + & + & + & + & $w k+$ & - & - \\
\hline $157 / 90$ & + & + & + & + & + & - & - \\
\hline $113 / 91$ & + & + & + & + & + & - & - \\
\hline $128 / 91$ & + & + & + & + & + & - & - \\
\hline $160 / 91$ & + & + & + & + & + & - & - \\
\hline $80 / 92$ & + & + & + & + & + & - & - \\
\hline $82 / 92$ & + & + & + & + & + & - & - \\
\hline $115 / 91$ & + & + & + & + & - & + & - \\
\hline $99 / 92$ & + & + & + & + & - & + & - \\
\hline $71 / 87$ & + & + & + & + & - & - & - \\
\hline $186 / 90$ & + & + & + & + & - & - & - \\
\hline $06 / 91$ & + & + & + & + & - & - & - \\
\hline $116 / 91$ & + & + & + & + & - & - & - \\
\hline $125 / 91$ & + & + & + & + & - & - & - \\
\hline $30 / 92$ & + & + & + & + & - & - & - \\
\hline $48 / 92$ & + & + & + & + & - & - & - \\
\hline $76 / 92$ & + & + & + & + & - & - & - \\
\hline $04 / 93$ & + & + & + & + & - & - & - \\
\hline $124 / 91$ & + & + & $w k+$ & $w k+$ & - & - & - \\
\hline $173 / 91$ & + & + & + & - & + & + & - \\
\hline $29 / 92$ & + & + & + & - & $w k+$ & - & $w k+$ \\
\hline $101 / 90$ & + & + & + & - & + & - & - \\
\hline $98 / 88$ & + & + & - & + & - & - & - \\
\hline $\mathrm{T} 3 / 89$ & + & + & - & + & - & - & - \\
\hline $\mathrm{RB}(\mathrm{I})$ & + & - & + & + & + & + & + \\
\hline SRCV(III) & + & - & + & + & - & + & - \\
\hline
\end{tabular}

longer be considered a universal reagent for identification of IHNV by immunofluorescence.

In contrast, all 27 of the French isolates of IHNV reacted with $\mathrm{MAb} 2 \mathrm{NH} 105 \mathrm{~B}$, which previously had been considered a specific antibody identifying electropherotype 2 (indeed, reference isolates RB and SRCV did not react); but only 2 of the French isolates displayed the same reactivity pattern as the WRAC isolate (electropherotype 2) using the 4 other MAbs. Two of the French isolates, 69/87 (same as INRA 32/87) and 71/87, were previously electropherotyped by Arkush et al. (1989) and were not recognized as belonging to electropherotype 2 . These results taken together suggest that the relationship between electropherotyping and antigenicity with respect to MAb 2NH105B could be less strict than formerly thought.

Twenty-five of the French isolates reacted with MAb $1 \mathrm{NC} 027 \mathrm{G}$, and 24 of them reacted to a lesser extent with MAb 1NH139P and 13 were recognized by MAb 1NDW191. Among those 25 French isolates reacting with MAb 1NCO27G, 3 failed to react with MAb 1NH139P, but were recognized by MAb 1DW191 instead.

One MAb, 3GH127B, reacted with only 1 of the French isolates (29/92), but distinguished it from the 2 other isolates that shared epitope 1NDW19I but lacked epitope 1NH139P. However, this MAb is noted for virus neutralization rather than for immunofluorescence.

Two isolates, $98 / 88$ and T3/89, were only recognized by MAbs 2NH105B and 1NH139P, and appeared distinct from other isolates. Both isolates originated from stocks of rainbow trout from 2 farms located along a short coastal river. Overt IHN had occurred on the upstream farm during spring 1988 (isolate 98/88) and in January 1989; IHNV was recovered from ovarian fluids of broodfish at the downstream farm (isolate T3/89). Two other isolates, $147 / 90$ and $157 / 90$, possibly shared a common origin as $147 / 90$ was recovered from diseased alevins at one farm while $157 / 90$ was isolated 
from the broodstock at the egg supplier's farming facility approximately $300 \mathrm{~km}$ away.

Other than the examples presented above, our results did not provide much epidemiological identifying relationships between the IIF reactivity patterns of the isolates and their host or geographic origins, or date of isolation. As previously reported by Ristow \& Arnzen de Avila (1991) for U.S. isolates of IHNV, there were differences among the French isolates of IHNV based on reactivity with MAbs made against the nucleoprotein or glycoprotein. It thus appears that viruses $51 / 90$ and $172 / 91$ display more epitopes with respect to the MAbs used for IF testing than virus strains $69 / 87$ and $71 / 87$ which were isolated 4 and 5 yr earlier respectively. Similarly, isolate 172/91, which came from the same broodfish stock as isolate T3/89, appeared to be antigenically different 2 yr later.

Since all the French isolates originated from rainbow trout, we have no indications of the possible differences in virulence for different species of salmonids as has been reported in a recent investigation with American isolates (La Patra et al. 1993). However, 2 waterborne infection trials performed independently using brown trout Salmo trutta with isolate 69/87 failed to produce mortality (M. Dorson \& J. Castric pers. cormm.), while challenges performed in the USA using American isolates were successful (La Patra \& Fryer 1990).

Our results on the antigenic typing of the 27 French IHNV isolates by a panel of MAbs show considerable variation among the epitopes on the nucleoprotein. Antigenic differences observed among American isolates (Ristow \& Arnzen de Avila 1991) also appeared in French isolates as variations around the constant epitope 2NH105B. Such antigenic behaviour makes the French isolates a somewhat separate entity inasmuch as the electropherotypes of 2 of them did not fall into the previously defined groups of IHNV. This suggests that some of the French isolates could have evolved in rainbow trout separately for some time before being identified in France in 1987. Practically speaking, any universal IHNV reagent for IF should now contain MAb 2NH105B in addition to MAb 1NDW14 if intended for use in Europe.

Acknowledgements. We acknowledge the assistance of Mrs Nicole Deschamps in typing the manuscript.

\section{LITERATURE CITED}

Anonymous (1987). Infectious haematopoietic necrosis in France. Bull. off. int. Epiz. 99: 38

Arkush, K. D., Bovo, G., de Kinkelin, P., Winton, J. R., Wingfield, W. H., Hedrick, R. P. (1989). Biochemical and antigenic properties of the first isolates of infectious haematopoietic necrosis virus from salmonid fish in Europe. J aquat. Anim. Health 1 148-153

Bovo, G., Giorgetti, G., Jørgensen, P. E. V., Olesen, N. J. (1987). Infectious haematopoietic necrosis: first detection in Italy. Bull. Eur. Ass. Fish Pathol. 7: 124

Busch, R. A. (1983). Viral disease considerations in the commercial trout industry in Idaho. In: Leong, J. C., Barilla, T. Y (eds.) Workshop on viral diseases of salmonid fishes in the Columbia River Basin. Special Publication, Bonneville Power Administration, Portland, OR, p. 84-100

Chen, S. N., Kou, G. H., Hedrick, R. P., Fryer, J. L. (1985). The occurrence of viral infections of fish in Taiwan. In: Ellis, A. E. (ed.) Fish and shellfish pathology. Academic Press, London, p. 313-319

Fijan, N., Sulimanovic, D., Bearzotti, M., Muzinic, D., Zwillenberg, L. O., Chilmonczyk, S., Vautherot, J. F., de Kinkelin, P. (1983). Some properties of the Epithelioma papulosum cyprini (EPC) cell line from carp (Cyprinus carpio). Annls Viroi., Inst. Pasteur 134E: 207-220

Hsu, Y.-L., Engelking, H. M., Leong, J. C. (1986). Occurrence of different types of infectious haematopoietic necrosis virus in fish Appl environ. Microbiol 52: 1353-1361

de Kinkelin, P., Michel, C., Ghittino, P. (eds.) (1985). Précis de pathologie des poissons. Office international des Epizooties, Institut National de la Recherche Agronomique, Paris

La Patra, S. E., Fryer, J. L. (1990). Susceptibility of brown trout (Salmo trutta) to infectious hematopoietic necrosis virus. Bull. Eur. Ass. Fish Pathol. 10: 125-127

La Patra, S. E., Fryer, J. L., Rohovec, J. S. (1993). Virulence comparison of different electropherotypes of infectious hematopoietic virus. Dis. aquat. Org. 16: 115-120

Leong, J. C., Hsu, Y. L., Engelking, H. M., Mulcahy, D. (1981). Strains of infectious haematopoietic necrosis virus may be identified by structural protein differences. Dev. biol. Standard. 49: 43-55

Luqi, N., Zhizhuang, Z. (1988). The epidemiology of IHN and IPN of rainbow trout in northeast China. Shui Chan Xue Bao (J. Fish. China) 12: 327-332

McCain, B. B., Fryer, J. L., Pilcher, K. S. (1971). Antigenic relationships in a group of three viruses of salmonid fish by cross neutralization. Proc. Soc. exp. Biol. Med. 137: $1042-1046$

Ristow, S. S., Arnzen, J. M. (1989). Development of monoclonal antibodies that recognize a Type 2 specific and a common epitope on the nucleoprotein of infectious haematopoietic necrosis virus. J. aquat. Anim. Health 1. $119-125$

Ristow, S. S., Arnzen de Avila, J. (1991). Monoclonal antibodies to the glycoprotein and nucleoprotein of infectious haematopoietic necrosis virus (IHNV) reveal differences among isolates of the virus by fluorescence, neutralisation and electrophoresis. Dis. aquat. Org. 11. 105-115

Sano, T., Nishimura, T., Okamoto, N., Yamazaki, T., Hanada, H., Watanabe, Y (1977). Studies on viral diseases of Japanese fishes. VI. Infectious haematopoietic necrosis (IHN) of salmonids in the mainland of Japan. J. Tokyo Univ. Fish. 63: 81-85

Winton, J. R., Arakawa, C. K., Lannan, C. N., Fryer, J. L. (1988). Neutralizing monoclonal antibodies recognize antigenic variants among isolates of infectious hematopoietic necrosis virus. Dis. aquat. Org. 4: 199-204

Wolf, K. (1988). Fish viruses and fish viral diseases, 1st edn. Cornell University Press, New York 